Thomas C. Mainprize MD,

J. Roger Maltby MB B CHIR FFARCS FRCPC

\title{
Amniotic fluid embolism: a report of four probable cases
}

Four probable cases of amniotic fuid embolism (AFE) are reviewed. The outcome appeared to be determined by the severity of the insult, and possibly the gestation of the pregnancy, rather than the management of the AFE. Two cases occurred during early labour; neither patient recovered consciousness. One died two weeks later and the other suffered severe permanent cerebral damage. The other two cases occurred during dilatation and curettage, one for therapeutic abortion at fourteen weeks gestation and the other for missed abortion at twenty weeks gestation. Both patients made full recoveries.

Disseminated intravascular coagulation (DIC) was a feature of all four cases. In the patients in labour it occurred almost immediately. In those undergoing dilatation and curettage it occurred after the patients had apparently recovered but were under observation in the intensive care unit.

Amniotic fluid embolism can occur during an apparently uneventful labour. It should also be suspected when unexplained collapse occurs during second trimester dilatation and curettage. Because severe DIC may follow, such patients should be transferred immediately to a centre with full haemotology services.

\section{Key words}

COMPLICATIONS: amniotic fluid embolism; ANAESTHESIA: obstetric.

From the Department of Obstetrics and Gynaecology and The Department of Anaesthesia, Foothills Hospital at the University of Calgary, Calgary, Alberta.

Address correspondence to: Dr. J. Roger Maltby, Department of Anaesthesia, Foothills Hospital at the University of Calgary, 1403-29th Street NW, Calgary, Alberta, Canada T2N 2T9.
Amniotic fluid embolism (AFE) is a dramatic and frequently fatal complication of pregnancy and is a cause of maternal death which remains unpredictable and largely unpreventable. ${ }^{1}$ The diagnosis is confirmed by the histological identification of fetal squames in the lungs. However, a presumptive clinical diagnosis may be made when a patient collapses suddenly, usually after rupture of the membranes, during violent uterine contractions. The collapse may be accompanied by a convulsion or muscular twitching, usually with dyspnoea and cyanosis. Coagulation defects may be associated with postpartum haemorrhage and bleeding from other sites. $^{2}$

Not all cases are typical. The condition may occur during apparently normal labour and also during second trimester dilatation and curettage. During the years 1974-84 four cases occurred in the Foothills Hospital, Calgary. These demonstrate the diversity of both the presentation and outcome of AFE.

\section{Case reports}

Case 1

A thirty-year-old female, G4 P3, weighing $78 \mathrm{~kg}$, was admitted to hospital at 37 weeks gestation in early labour following spontaneous rupture of the membranes.

An oxytocin infusion was started at a rate of four milli-units per minute to augment mild uterine contractions. Fifteen minutes later, without any warning, and with still only mild contractions, the patient had a grand mal convulsion, became cyanotic and, within two minutes, pulseless. Cardiopulmonary resuscitation was immediately instituted. Five minutes late a Caesarean section was commenced while external cardiac massage was continued. A live female infant weighing $2,600 \mathrm{gm}$ was delivered with Apgar scores of 1 and 7.

Within one hour of the initial collapse bleeding 
appeared from the incision and intravenous sites. Coagulation tests confirmed disseminated intravascular coagulation (DIC) which was successfully treated.

Mechanical ventilation was continued postoperatively but there was no recovery of cerebral function. After seven days the EEG showed no brain activity and life support was discontinued.

\section{Case 2}

An eighteen-year-old female, G1 P0, weighing $67 \mathrm{~kg}$, was admitted at 34 weeks gestation in premature labour with ruptured membranes.

At $1930 \mathrm{hrs}$ an isoxuprine infusion $\left(400 \mathrm{mg} \cdot \mathrm{L}^{-1}\right)$ was commenced at a rate of $9.6 \mathrm{mg} \cdot \mathrm{hr}^{-1}$ to inhibit uterine contractions. Ten minutes later she complained of nausea and almost immediately had a grand mal convulsion followed by cardiac arrest. Cardiopulmonary resuscitation was started immediately and was successful. However, she did not recover consciousness and was transferred to the intensive care unit (ICU).

At $2110 \mathrm{hrs}$ she vomited blood and began bleeding from intravenous puncture sites, vagina and urinary tract. Laboratory tests confirmed DIC which was successfully treated. A premature infant, delivered vaginally with forceps, died within one hour.

She did not recover consciousness and required ventilation for the next two weeks. After this she was weaned from the ventilator and was transferred to her home town for long-term care.

\section{Case 3}

A healthy eighteen-year-old female, G2 P1, weighing $59 \mathrm{~kg}$, was admitted as a day-care patient at 14 weeks gestation for therapeutic abortion. Anaesthesia was induced using thiopentone $250 \mathrm{mg}$ and continued with fentanyl $100 \mu \mathrm{g}$ and nitrous oxide 75 per cent in oxygen at a flow rate of eight litres per minute. During the dilatation and curettage the patient suddenly became cyanotic but continued to breathe normally with good air entry and clear lung fields. Nitrous oxide was discontinued and 100 per cent oxygen given. Blood pressure became unrecordable although she still had a weak palpable pulse. Cardiac arrest did not occur. Further treatment was being considered when her colour improved, the blood pressure rose, and consciousness returned.
The patient was admitted to the ICU for further observation.

Within two hours of the initial collapse vaginal bleeding increased. Laboratory tests confirmed DIC. This was successfully treated and the patient made a full recovery.

\section{Case 4}

A thirty-one-year old female, G3 P2, weighing $60 \mathrm{~kg}$, was admitted to hospital two weeks after intrauterine death had occurred at 20 weeks gestation. The uterus was 12-14 weeks size. Laboratory tests for coagulation were normal on two occasions and she was scheduled for dilatation and curettage.

No premedication was given. Anaesthesia was induced with thiopentone and maintained with nitrous oxide 50 per cent in oxygen. A considerable amount of necrotic tissue was removed and, because the uterus was bulky, ergometrine $0.25 \mathrm{mg}$ was given intravenously. About one minute later the patient coughed, became deeply cyanotic, with marked congestion of the neck and face and stopped breathing. Her pulse was barely palpable, blood pressure was unrecordable and the EKG showed a tachycardia with marked ST depression. Her pupils were fixed and dilated. An endotracheal tube was immediately passed and she was ventilated with 100 per cent oxygen.

As in case 3 the diagnosis was not immediately apparent. Her condition did not deteriorate further and within twenty minutes her colour improved, her pupils began to react and the EKG returned to normal. Fifteen minutes later she started coughing on the endotracheal tube. Soon she was awake and breathing spontaneously. The endotracheal tube was removed and she was admitted to ICU. DIC supervened but this was successfully treated and she made a full recovery.

The clinical characteristics of each case are shown in Table $I$ and the coagulation defects in Table II.

\section{Discussion}

The clinical characteristics of the four cases in this series illustrate different presentations of amniotic fluid embolism. In neither of the two patients near term was the labour tumultuous. Apart from nausea in one of the patients, the onset was dramatic with a grand mal convulsion rapidly followed by cardiac 
TABLE I Clinical characteristics of cases

\begin{tabular}{|c|c|c|c|c|c|c|c|c|}
\hline Case & Age & $\begin{array}{l}\text { Weeks } \\
\text { gestation }\end{array}$ & $\begin{array}{l}\text { Pre-existing } \\
\text { disease }\end{array}$ & $\begin{array}{l}\text { Time of } \\
\text { presentation }\end{array}$ & $\begin{array}{l}\text { Presenting symp- } \\
\text { toms and signs }\end{array}$ & $\begin{array}{l}\text { Onset } \\
\text { of DIC }\end{array}$ & Treatment & Outcome \\
\hline 1 & 30 & 37 & $\begin{array}{l}\text { Remote atrial } \\
\text { septal defect } \\
\text { repair; mild } \\
\text { painless bleeding } \\
33 \text { weeks }\end{array}$ & Early labour & $\begin{array}{l}\text { Grand mal seizure, } \\
\text { cardio-vascular } \\
\text { collapse, corna }\end{array}$ & $<1$ hr & $\begin{array}{l}\mathrm{O}_{2}, \mathrm{CPR} \\
\text { Caesarean section } \\
\text { PRC } 29 \text { units } \\
\text { FFP } 35 \text { units }\end{array}$ & $\begin{array}{l}\text { Mother: death } \\
\text { after } 6 \text { days; } \\
\text { live infant }\end{array}$ \\
\hline 2 & 18 & 34 & $\begin{array}{l}\text { Threatened } \\
\text { abortion } \\
10 \text { weeks }\end{array}$ & $\begin{array}{l}\text { Premature } \\
\text { labour, on } \\
\text { isoxuprine } \\
\text { drip }\end{array}$ & $\begin{array}{l}\text { Nausea, grand mal } \\
\text { scizure, } \\
\text { CV collapse } \\
\text { coma }\end{array}$ & $<1 \mathrm{hr}$ & $\begin{array}{l}\text { Diazepam, } \mathrm{O}_{2}, \\
\text { intubation, } \mathrm{CPR} \\
\text { Vaginal delivery } \\
\text { in ICU }\end{array}$ & $\begin{array}{l}\text { Mother: permanent } \\
\text { cerebral damage; } \\
\text { baby died within } \\
1 \mathrm{hr}\end{array}$ \\
\hline 3 & 18 & 14 & Nil & $\begin{array}{l}\text { During } \\
D \& C \text { for } \\
\text { therapeutic } \\
\text { abortion }\end{array}$ & $\begin{array}{l}\text { Cyanosis, } \\
\text { CV collapse, } \\
\text { lungs clear }\end{array}$ & $<2 \mathrm{hr}$ & $\begin{array}{l}\mathrm{O}_{2} \\
\text { PRC } 8 \text { units } \\
\text { FFP } 6 \text { units }\end{array}$ & $\begin{array}{l}\text { Recovery from } \\
\text { collapse } 30 \mathrm{mins} \\
\text { recovery from } \\
\text { DIC } 18 \mathrm{hrs}\end{array}$ \\
\hline 4 & 31 & 22 & $\begin{array}{l}\text { Missed abortion } \\
20 \text { weeks }\end{array}$ & $\begin{array}{l}\text { During } \\
\text { D \& C } \\
\text { for missed } \\
\text { abortion }\end{array}$ & $\begin{array}{l}\text { Cough, } \\
\text { CV collapse, } \\
\text { cyanosis, } \\
\text { lungs clear }\end{array}$ & $<1 \mathrm{hr}$ & $\begin{array}{l}\mathrm{O}_{2} \text {, intubation, } \\
\text { IPPV } 30 \text { mins } \\
\text { PRC } 3 \text { units } \\
\text { FFP } 4 \text { units } \\
\text { Platelets } 6 \text { units } \\
\text { Cryoppt. } 10 \text { units }\end{array}$ & $\begin{array}{l}\text { Recovery from } \\
\text { collapse } 45 \text { mins; } \\
\text { recovery from } \\
\text { DIC } 24 \text { hrs }\end{array}$ \\
\hline
\end{tabular}

$\mathrm{CV}=$ cardiovascular. $\mathrm{CPR}=$ cardio-pulmonary resuscitation. $\mathrm{PRC}=$ packed red blood cells. FFP $=$ fresh frozen plasma. $\mathrm{D} \& \mathrm{C}=$ Dilatation \& curettage.

arrest. Immediate intensive resuscitation did not prevent permanent brain damage. Severe coagulopathy occurred within one hour and was successfully managed with fresh frozen plasma and packed red cells.

In the two patients undergoing dilatation and curettage, cyanosis and profound hypotension occurred without warning. One patient continued to breathe normally, the other became apnoeic. The critical condition continued, despite 100 per cent oxygen, for about 20 minutes before rapid spontaneous improvement occurred. Profound cardiovascular collapse and cyanosis, not proceeding to cardiac arrest, were the only features. The aetiology was not immediately obvious. In one case the possibility of crossed gas lines was considered and the oxygen supply changed from pipeline to the cylinder on the anaesthetic machine. The intravenous fluid, which might have been contaminated, was also changed. Both patients started improving before a firm diagnosis was made. Each was admitted to the ICU for observation with a provisional diagnosis of AFE.

The presenting features in patients who develop
$\mathrm{AFE}$ are: respiratory failure and cyanosis (51 per cent), cardiovascular collapse (27 per cent), convulsions (10 per cent) and haemorrhage (12 per cent). ${ }^{3}$ of patients surviving the initial insult for more than one hour, 40 per cent will develop DIC. ${ }^{4}$ Any condition which may cause the acute onset of these symptoms must be considered. The differential diagnosis ${ }^{3,5}$ therefore includes abruptio placentae, ruptured or inverted uterus; pulmonary thromboembolism; cerebral insults including eclampsia, epilepsy and ruptured intracranial aneurysm; idiosyncratic or anaphylactic drug reactions; and misconnected gas lines.

By a process of exclusion a diagnosis of probable AFE can be made with reasonable confidence on clinical grounds alone. ${ }^{3,5,7}$ Even in patients with confirmed AFE the investigations of chest $x$-ray, EKG and pulmonary angiography are non-specific. They have been reported as abnormal by some authors ${ }^{8-11}$ and normal by others. ${ }^{7,12,13}$ Diagnosis is usually confirmed at autopsy, ${ }^{14,15}$ although there are now several reports of confirmed AFE in patients who survived. Confirmation is obtained by histological demonstration of fetal squames (Nile 
TABLE II Coagulation function tests - maximally abnormal values

\begin{tabular}{|c|c|c|c|c|c|}
\hline Case & $\begin{array}{l}\text { Time from } \\
\text { onset (hrs) }\end{array}$ & $\begin{array}{l}P T(\sec ) \\
(11-13)\end{array}$ & $\begin{array}{l}P T T(\mathrm{sec}) \\
(36-55)\end{array}$ & $\begin{array}{l}\text { Fibrinogen }\left(g \cdot L^{-1}\right) \\
(1.5-4.5)\end{array}$ & $\begin{array}{l}\text { FDP }\left(\mathrm{mg} \cdot \mathrm{L}^{-1}\right) \\
\text { (less than 40) }\end{array}$ \\
\hline 1 & 5 & 19.1 & 200 & 0.29 & $640-1280$ \\
\hline 2 & 2 & 50 & 421 & 0.15 & 160 \\
\hline 3 & 6 & no clot & no clot & $0.59 *$ & $320-640^{*}$ \\
\hline 4 & 1 & 50 & 200 & none & $1280-2560$ \\
\hline
\end{tabular}

blue $^{3}$ or Papanicolaou stain ${ }^{16}$ ), keratin (AyoubShklar stain ${ }^{17}$ ), fat (oil red 0 stain ${ }^{17}$ ), lanugo and/or hair in blood collected from the pulmonary artery via a Swan-Ganz catheter, ${ }^{12,17,18}$ pulmonary angiography, ${ }^{10}$ or from sputum. ${ }^{9,19}$ Haematoxylin and eosin stain is reported as unreliable. ${ }^{20}$ Garland and Thompson ${ }^{21}$ believe their antiserum to human keratin is more sensitive in diagnosing amniotic fluid debris.

In the cases reported here the diagnosis was only confirmed histologically in the patient who died. At autopsy fetal squames were present in her lungs.

Mayer is usually credited with the first reported case of amniotic fluid embolism, published in 1926. ${ }^{22}$ However, Attwood has recently suggested ${ }^{23}$ that a postmortem description by Baillie in 1825 may represent the first recorded case.

The reported incidence varies from one in $8,000^{24}$ to one in $80,000^{25}$ live births. Four probable cases occurred during 34,366 deliveries at the Foothills Hospital, giving an incidence of one in 8600 live births. Although three of these four women survived, a review of the English literature up to 1979 showed a survival rate of only 14 per cent. $^{3}$

In Morgan's review ${ }^{3}$ of 272 cases, 90 per cent of cases occurred during labour; 28 per cent in tumultuous labour and 22 per cent in oxytocin stimulated labour. A small number complicated intrauterine deaths. The mean age of occurrence was 32 years with a range of 15 to 48 years. The association with intrauterine contraceptive devices remains unclear. ${ }^{2}$ AFE are also reported after second trimester intra-amniotic installations, $8,14,26$ where the increased intrauterine pressure may play a role, ${ }^{3}$ and after dilatation and curettage..$^{5,6,9,27}$
For AFE to occur, the chorioamniotic membrane must rupture, exposing amniotic fluid to a venous channel either at the endocervical veins, beneath the placenta or at the site of uterine trauma. ${ }^{28}$ This may occur with normal labour, abruptio placentae, or any uterine manipulations such as Cacsarean section, manual removal of placenta, artificial rupture of membranes or insertion of an intrauterine pressure catheter. ${ }^{3}$ Abruption of the placenta due to fetal cord entanglement and a tear in the membranes producing fatal AFE is reported by Corridan $e t a l .{ }^{29}$ However, the volume of amniotic fluid required to cause maternal symptoms and/or death, is not known. Plauché ${ }^{30}$ claims to have identified amniotic fluid debris in two patients who showed no clinical or haemodynamic changes of AFE, but Sparr and Pritchard ${ }^{31}$ were unable to demonstrate that amniotic fluid escapes into the maternal circulation during labour in 28 patients. If Plauché is correct the possibility of anaphylaxis ${ }^{3}$ as an aetiologic agent by virtue of prior sensitization is feasible although this remains an unconfirmed hypothesis.

Once in the matemal circulation, amniotic fluid is transported to the lungs and causes obstruction of the vasculature. This obstruction is accompanied by pulmonary hypertension, ventilation-perfusion inequality and cardiac failure..$^{3,12,32}$ The release of a Factor $\mathrm{X}$ activator ${ }^{3}$ may worsen the obstructive changes. The subsequent activation of lysis factors completes the vicious cycle of DIC and haemorrhage.

Although AFE is a rare event it carries a high mortality and case reports continue to appear in the literature. ${ }^{21,27,29,33}$ The maternal mortality rate from sepsis and haemorrhage has declined and recent reports of survivals from AFE sug- 
gest there may be a similar trend in this condition. $^{8,10,11,17,32.34,35}$ Even if this is so, the reason is not clear, although it could be due to a greater awareness of AFE with better management of complications.

AFE complications vary. Haematological changes of DIC occur in most patients although bleeding may not be observed. Twenty-four per cent of patients develop pulmonary oedema, probably related to excessive fluid administration during resuscitation. Acute renal failure secondary to prolonged hypotension, and cerebral damage from anoxia are uncommon. The overall death rate is 86 per cent and, of these, 24 per cent die in the first hour. ${ }^{3}$ Causes of death include haemorrhage from DIC, circulatory collapse, and right heart failure with pulmonary hypertension, secondary to massive cardiac tamponade. ${ }^{12}$

Since there is no specific therapy for AFE general supportive measures are imperative. ${ }^{3}$ These include cardiopulmonary resuscitation, correction of the bleeding diathesis, and blood volume replacement. Central venous pressure or pulmonary artery pressure monitoring are advisable. ${ }^{36}$ The value of digoxin, diuretics, vasodilators, dextran, corticosteroids, and antiprostaglandins remains unclear. ${ }^{3.36}$ It is possible that the outcome, as in our cases, is determined more by the severity of the initial insult or the gestational age at occurrence than the subsequent management.

The cases described demonstrate three important points about amniotic fluid embolism: (1) the condition may occur when contractions are mild rather than during tumultuous labour, (2) it may occur during second trimester dilatation and curettage and, (3) despite apparent recovery, patients may later develop DIC. When AFE is suspected in a smaller hospital the patient should be transferred immediately to a centre with full haematology services without waiting to see if DIC is going to occur.

\section{Acknowledgements}

The authors thank those members of the Departments of Anaesthesia, Obstetrics and Gynaecology, Intensive Care and Haematology who treated these patients; Dr. George Carson for helpful criticism of the manuscript; and Mrs. Caroline Harris for secretarial assistance.

\section{References}

1 Shnider SM, Moya F. Amniotic fluid embolism. Anesthesiology 1961; 22: 108-19.

2 Department of Health and Social Security. Report on confidential enquiries into maternal deaths in England and Wales 1976-78; 96-100. London: Her Majesty's Stationery Office 1982.

3 Morgan M. Amniotic fluid embolism. Anaesthesia 1979; 34: 20-32.

4 Anderson DG. Amniotic fluid embolism. A reevaluation. Am J Obstet Gynecol 1967; 98: 336-48.

5 Cromey $M G$, Taylor PJ, Cummings DC. Probable amniotic fluid embolism after first trimester pregnancy termination - a case report. J Reproductive Med 1983; 28: 209-11.

6 Lees DE. Shin Y. MacNamara TE. Probable amniotic fluid embolism during curettage for a missed absorption: a case report. Anesth Analg 1977; 56: $739-42$.

7 Lumley $J$, Owen R, Morgan M. Amniotic fluid embolism. A report of three cases. Anaesthesia 1979; 34: 33-6.

8 Ballas $S$, Lessing IB, Michowitz $M$. Amniotic fluid embolism and disseminated intravascular coagulation complicating hypertonic saline-induced absorption. Postgrad Med J 1983; 59: 127-9.

9 Stromme WB, Fromke VL. Amniotic fluid embolism and disseminated intravascular coagulation after evacuation of missed abortion. Obstet Gynec 1978; 52: 76s-80s.

10 Dolyniuk M, Orfei E, Vania H, Karlman R, Tomich $P$. Rapid diagnosis of amniotic fluid embolism. Obstet Gynecol 1983; 61: 28s-30s.

11 Taenaka N, Shimada Y, Kawai M, Yoshiya I, Kosaki $G$. Survival from DIC following amniotic fluid embolism. Anaesthesia 1981; 36: 389-93.

12 Schaerf RH, de Campo T, Civetta JM. Hemodynamic alterations and rapid diagnosis in a case of amniotic fluid embolus. Anesthesiology 1977; 46: 155-7.

13 Sterner S, Campbell B, Davies S. Amniotic flu:d embolism. Ann Emerg Med 1984; 13: 343-5.

14 Grimes DA, Cates W Jr. Fatal amniotic fluid embolism during induced abortion, 1972-1975. South Med J 1977; 30: 1325-6.

15 Attwood HD. Amniotic fluid embolism. Pathol Annu 1972; 7: 145-72.

16 Masson RG, Rugieri J, Siddiqui MM. Amniotic fluid embolism: definitive diagnosis in a survivor. Am Rev Respir Dis 1979; 120: 187-92. 
17 Duff $P$, Engelsgjerd $B$, Zingery $L W, H u f f R W$, Montiel $M M$. Hemodynamic observations in a patient with intrapartum fluid embolism. Am J Obstet Gynecol 1983; 146: I12-5.

18 Botero SD. Holmquist ND. Cytologic diagnosis of amniotic fluid embolus - report of a case. Acta Cytol (Baltimore) 1979; 23: 465-6.

19 Tuck CS. Amniotic fluid embolus. Proc Royal Soc Med 1972; 65: 94-5.

20 Roche WD, Norris $H J$. Detection and significance of maternal amniotic fluid embolism. Obstet Gynecol 1974; 43: 729-31.

21 Garland IWC, Thompson WD. Diagnosis of amniotic fluid embolism using an antiserum to human keratin. J Clin Pathol 1983; 36: 625-7.

22 Mayer $J R$. Embolis pulmonar-caseosa. Brazil Medico 1926; 2: 301-3.

23 Attwood $H D$. Matthew Baillie - a possible early description of amniotic fluid embolism. Aust NZ J Obstet Gynaecol 1979; 19: 176-7.

24 Steiner PE, Lushbaugh CC. Maternal pulmonary embolism by amniotic fluid. JAMA 1941; 117: 1340-5.

25 Lewis TLT. Progress in clinical obstetrics and gynecology. 2nd ed. London: Churchill Livingstone $1964, \mathrm{p} 48$.

26 Guidotti RJ, Grimes DA, Cates W Jr. Fatal amniotic fluid embolism during legally induced abortion, United States, 1972 to 1978 . Am J Obstet Gynecol 1981; 141: 257-61.

27 Cates W Jr, Boyd C, Halvorson-Boyd G, Holck S, Gilchrist $T F$. Death from amniotic fluid embolism and disseminated intravascular coagulation after a curettage abortion. Am J Obstet Gynecol 1981; 141: 346-8.

28 Turner $R$, Gusack $M$. Massive amniotic fluid embolism. Ann Emerg Med 1984; 13: 359-61.

29 Corridan $M$, Kendall ED, Begg JD. Cord entanglement causing premature placental separation and amniotic fluid embolism. Br J Obstet Gynccol 1980; 87: 935-40.

30 Plauché WC. Amniotic fluid embolism (letter to the editor). Am J Obstet Gynecol 1983; 147: 982.

31 Sparr RA, Pritchard JA. Studies to detect the escape of amniotic fluid into the maternal circulation during parturition. Surg Gynecol Obstet 1958; 107 $560-4$.

32 Moore PG, James OF, Saltos $N$. Severe amniotic fluid embolism: case report with hemodynamic findings. Anaesth Intensive Care 1982; 10: 40-4.

33 Barrows $J J$. A documented case of amniotic fluid embolism presenting as acute fetal distress. Am J Obstet Gynecol 1982; 143: 599-600.

34 Rodgers GP, Heymach GJ. Cryoprecipitate therapy in amniotic fluid embolization. Am J Med 1984; 76: 916-20.

35 Kern $S B, D$ uff $P$. Localized amniotic fluid embolism presenting as ovarian vein thrombosis and refractory postoperative fever. Am J Clin Pathol 1981; 76: $476-80$.

36 Editorial. Amniotic-fluid embolism. Lancet 1979; 2: 398-400.

Résumé

Quatre cas probable d'embolie de liquide amiotique (AFE) sont revus. Le résultat final est apparamment déterminé par la sévérité de l'insulte et possiblement le temps de la grossesse plus que par la conduite thérapeuti. que. Deux cas sont survenus tôt lors du travail; accune patiente $n^{\prime}$ a retrouvé connaissance. Une est décédée une semaine plus tard alors que l'autre a souffert de dommage cérébral permanent sévère. Les deux autres cas sont survenus lors de la dilatation et curetage, une pour avortement thérapeutique à la quatorzième semaine de la gestation et l'autre pour avortement à la vingtième semaine de gestation. Ces deux patientes n'ont accusé aucun dommage après l'accident.

La coagulation intravasculaire disséminée (DIC) était présente pour les quatre cas. Pour les patientes au travail ce syndrome est survenu presqu'immédiatement. Pour celles subissant une dilatation et curetage ce syndrome est survenu après que les patientes se sont rétablies mais étaient en observation aux soins intensifs.

L'embolie de liquide amiotique peut survenir apparemment lors d'un travail sans problème. Elle doit être suspectée lorsqu' un collapsus non expliqué survient lors d'une dilatation et curetage au second trimestre. Parce que une coagulation intravasculaire disséminée peut être provoquée, les patientes doivent être transférées à un centre fournissant des services d'hématologie. 